Diabetologia 11, 211-219 (1975)

(c) by Springer-Verlag 1975

\title{
A Radioreceptor-Assay for Glucagon: Binding of Enteroglucagon to Liver Plasma Membranes
}

\author{
J. J. Holst \\ Dept. of Gastroenterology A and Dept. of Clinical Chemistry, Bispebjerg Hospital, Copenhagen, Denmark \\ Received: November 13, 1974, and in revised form: March 17, 1975
}

\begin{abstract}
Summary. A radioreceptor-assay for glucagon was developed employing pig liver plasma membranes isolated by means of an aqueous two-phase polymer system. The assay is simple, precise, and has a detection limit of $40 \mathrm{pg} / \mathrm{ml}$. Acid-ethanol extracts of porcine intestinal mucosa and enteroglucagon purified by affinity chromatography interfered strongly with the binding of ${ }^{125} \mathrm{I}$-labelled glucagon. The affinity of enteroglucagon for the membranes was lower
\end{abstract}

than that of glucagon, but even physiological concentrations of the former interfere with glucagon binding, indicating that enteroglucagon may compete with pancreatic glucagon for binding to the hepatocyte under physiological conditions.

Key words: Glucagon, affinity chromatography, hormone receptor, radioligand assay, gastrointestinal hormones, radioimmunoassay.
The glucagon receptor of the plasma membranes of rat liver has been extensively studied (see recent reviews by Rodbell [1], Birnbaumer [2], and Rodbell [3]). It is, however, as yet unclear whether enteroglucagon $^{1}$ (see Moody [4] for recent review) interacts with the hepatic receptors [5-9]. In the present study the development of a radioreceptorassay [10] for glucagon and the interaction of different preparations of enteroglucagon with the glucagon receptor are described.

\section{Materials and Methods}

\section{Membrane Preparation}

Pig liver tissue was obtained by hepatectomy on anesthetized $30-40 \mathrm{~kg}$ Danish pigs. Plasma membranes were isolated using the aqueous two-phase polymer system of Brunette and Till [11], as described by Lesko et al. [12]. The high content of connective tissue in porcine liver made special treatment necessary and the following procedure was adopted. Livers were cut out of anesthetized pigs as quickly as possible and perfused via the portal vein with at least 2 liters of ice-cold physiological saline. When the major part of the liver had blanched, approximately $300 \mathrm{~g}$ of tissue were cut out of the blanched parts, minced roughly with scissors, and homogenized very briefly in a Waring type blender (Ballerup Senior Mixer, Copenhagen, Denmark, $30 \mathrm{sec}$ at position 1)

\footnotetext{
1 In this report enteroglucagon is defined as a substance (or substances), which is extractable from the gastrointestinal mucosa by techniques that would also extract and purify pancreatic glucagon, and which binds to certain crossreacting antiglucagon antibodies.
}

in the presence of 4 vol of ice-cold medium, according to Ray [13], i.e. $1 \mathrm{mM} \mathrm{NaHCO} 3(\mathrm{pH} 7.5)$ containing in addition $0.5 \mathrm{mM} \mathrm{CaCl}_{2}$. The homogenate was transferred to a sieve (pore size $1.5 \mathrm{~mm}$ ) and strained with a ladle. This step was repeated with a finer sieve $(0.9$ $\mathrm{mm})$. These procedures removed large amounts of connective tissue. The resulting mash $(100 \mathrm{~g})$ was diluted with 3 volumes of medium and homogenized with a Dounce homogenizer. The homogenate was diluted to 1.2 liters with medium and centrifuged in the $\mathrm{PR}_{2}$ (IEC) refrigerated centrifuge, according to Ray [13], in order to obtain the membrane-rich, low speed pellet.

The polymers were prepared as described by Lesko; it was found, however, that more than $48 \mathrm{hrs}$ were needed to ensure complete partition of the two phases. $96 \mathrm{hrs}$ were found to be satisfactory. The pellet was suspended in $80 \mathrm{ml}$ of the upper phase, 10 $\mathrm{ml}$ aliquots were pipetted into $850 \mathrm{ml}$ centrifuge tubes, to which were added $10 \mathrm{ml}$ of the lower phase solution. After mixing, the tubes were spun for $15 \mathrm{~min}$ at $2000 \times \mathrm{G}$ in a refrigerated centrifuge (Hettich), and the resulting precipitate suspended in another $80 \mathrm{ml}$ of upper phase, divided into eight parts etc., according to Lesko. The material from the interphase was finally washed thoroughly in Krebs-Ringer bicarbonate buffer and stored either frozen in dry ice or freeze-dried at $-20^{\circ} \mathrm{C}$. The whole procedure could be completed in less than 7 hours.

\section{I-Labelled Glucagon}

Monoiodinated, monocomponent 125I-labelled glucagon, prepared according to Jørgensen and Larsen [14], was a gift from U. D. Larsen, the Novo 
Research Institute, Copenhagen. Specific activity was from $100-200 \mu \mathrm{Ci} / \mu \mathrm{g}$, with an average of $160 \mu \mathrm{Ci}$ / $\mu \mathrm{g}$.

\section{Glucagon and Enteroglucagon}

Glucagon for standards was Monocomponent Glucagon, a gift from L. G. Heding, the Novo Research Institute, Copenhagen. A crude acid-ethanol extract of porcine intestinal mucosa (MUC 101), prepared according to Moody et al. [15], was a gift from F. Sundby, the Novo Research Institute. Furthermore, enteroglucagon was extracted from porcine intestinal mucosa according to Kenny and Say [16], as described by Murphy et al. [6], with the exception that mucosal tissue was obtained by scraping off the luminal surface of the total small intestine, excised as quickly as possible from an anesthetized pig, and frozen immediately afterwards between blocks of dry ice. After extraction the material was freeze-dried.

A part of the extract corresponding to $100 \mathrm{~g}$ of porcine intestinal mucosa was purified by affinity chromatography [17]. $20 \mathrm{ml}$ of anti-glucagon-immunosorbent was packed in a $20 \times 2 \mathrm{~cm}$ column and equilibrated with $0.05 \mathrm{M}$ sodium-phosphate buffer, pH 7.5, containing in addition $0.15 \mathrm{M} \mathrm{NaCl}$. The capacity of the column was determined by the application of $10 \mathrm{mg}$ of glucagon (NOVO), dissolved in 10 $\mathrm{ml} 0.4 \mathrm{M}$ sodium-phosphate buffer, $\mathrm{pH} 7.5$, containing in addition a trace amount of labelled glucagon. After extensive washing with the equilibration buffer, bound material was eluted by means of $1 \mathrm{M}$ ammonia. The UV-absorption of the column effluent was monitored continuously at $253 \mathrm{~nm}$ (Uvicord, LKB) and all fractions were analysed for radioactivity. The freezedried Kenny-extract was dissolved in $0.4 \mathrm{M}$ sodiumphosphate buffer, $\mathrm{pH} 7.5$, and applied to the column. After elution of unbound material, the column was washed extensively with $0.125 \mathrm{M}$ ammonium-bicarbonate and finally eluted with $1 \mathrm{M}$ ammonia, which yielded a higher recovery of glucagon from the column compared to acid ethanol, formic acid, dioxane, $\mathrm{HCl}$, urea, and Guanidine- $\mathrm{HCl}$. The eluted fractions were freeze-dried for subsequent radio-immunoassay, protein determination, and receptor-assay.

\section{Immunosorbent}

$10 \mathrm{ml}$ of antiserum 4304 [18], which binds enteroglucagon and pancreatic glucagon with the same energy, and which is routinely diluted 100000 times for assay use, was precipitated with sodium-sulphate according to Wide [19]. The precipitate was dissolved in $30 \mathrm{ml}$ phosphate buffer, $0.05 \mathrm{M}, \mathrm{NaCl} 0.5 \mathrm{M}, \mathrm{pH}$
6.5, to which was added $35 \mathrm{ml}$ CNBr-activated Sepharose $4 \mathbf{B}^{\circledast}$ (Pharmacia, Uppsala) freshly prepared according to the manufacturer's instructions. The mixture was allowed to react overnight, treated with $1 \mathrm{M}$ Glycine at $\mathrm{pH} 8.5$ for $2 \mathrm{hrs}$ and washed extensively with buffers of high ionic strength and varying $\mathrm{pH}$ as advised by the manufacturer. The immunosorbent was tested in a solid-phase radioimmunoassay system, a modification of a previously described technique [20], and enteroglucagon (MUC 101) and pancreatic glucagon were still bound with identical affinity. The immunosorbent was stored at $4^{\circ} \mathrm{C}$, and was found to be stable for more than six months.

\section{Radioimmunoassay}

Radioimmunoassay [18] was performed using an ethanol precipitation technique [21]. The antiserum used, 4304 [18], is supposed to measure enteroglucagon quantitatively against standards of pancreatic glucagon, because dilution curves of pancreatic glucagon and extracts of intestinal mucosa (MUC 101) are superimposable over any concentration range. The detection limit is $15 \mathrm{pg} / \mathrm{ml}$ and the within-assay coefficient of variation is 0.05 in the working range $(25-500 \mathrm{pg} / \mathrm{ml})$. During oral glucose tolerance tests, marked increases in total glucagon concentration are found with this antiserum.

\section{Radioreceptor-Assay}

Standards or samples were made up in Krebs-Ringer bicarbonate buffer, containing in addition $1 \%$ (w/v) Gelatine. For evaluation of non-specific binding a standard of $200 \mathrm{ng} / \mathrm{ml}$ was included in all experiments. The buffer was gassed with an oxygencarbon dioxide mixture $(96 \% / 4 \%)$ and kept in a bath at $37^{\circ} \mathrm{C}$. pH was $7.4 .2 \mathrm{ml}$ of standard or sample were mixed with $200 \mu \mathrm{g}$ of membranes ${ }^{2}$, which were suspended in distilled water immediately before use. The tubes were gently rotated for $30 \mathrm{~min}$ at room temperature. Then $100 \mathrm{pg}{ }^{125}$ I-labelled glucagon was added to the mixture, and incubation was continued for 15 minutes. Separation was performed either by Millipore filtration (Swinnex ${ }^{\circledR}$ filter holders and EGWP filters) or by centrifugation at $3000 \times \mathrm{G}$ for $10 \mathrm{~min}$ followed by 3 washes with incubation buffer. Filter discs or precipitates were counted in an automatic gamma scintillator (Selektronik, Denmark). All samples and standards were assayed in duplicate.

\footnotetext{
2 Protein analysis according to Lowry et al. [22]; before analysis the membrane suspension and albumin standards were heated in equal volumes of $1 \mathrm{~N} \mathrm{NaOH}$ until completely dissolved.
} 
Specificity of the receptor assay was examined by incubation of membranes with high concentrations of gastrin (synthetic human gastrin-17, obtained from ICI, Cheshire, England), secretin (purified natural porcine secretin, a gift from V. Mutt, GIH-laboratory, Stockholm Sweden), Vasoactive Intestinal Polypeptide (a gift from E. K. Frandsen, the Novo Research Institute, who received the peptide as a gift from S. I. Said, Veterans Administration Hospital, University of Texas), insulin (highly purified porcine insulin, Monocomponent insulin, a gift from L. G. Heding, the Novo Research Institute), and cholecystokinin (10\% pure, from the GIH-laboratory, Stockholm, Sweden). Polyacrylamide gel-electrophoresis was performed by means of a Quickfit apparatus as a modification of System 3, according to Maurer [23]. Gels were 20\% acrylamide in Tris- $\mathrm{HCl}$ buffer at $\mathrm{pH} 8.9$, which contained in addition $8 \mathrm{M}$ Urea (analytical grade); compartment buffer was TrisGlycine at pH 8.3. Samples were applied in $8 \mathrm{M}$ Urea, $10 \%$ sucrose, and bromophenolblue added as a marker. Electrophoresis was performed at $2 \mathrm{mAmp} / \mathrm{tube}$ until the colour marker had reached the bottom of the tube. The gels were cut into sections of $2 \mathrm{~mm}$, which were eluted overnight with radioimmunoassay buffer [18], followed by radioimmunoassay. Other tubes were stained with amido black. Labelled and unlabelled glucagon was applied to control-tubes. These were either counted or assayed for glucagon content.

\section{Results}

By means of the aqueous two-phase polymer system large amounts of membrane material were isolated from pig liver; $200-300 \mathrm{mg}$ of membrane protein [22] were obtained in each of 5 experiments. From initial experiments, in which labelled hormone alone or labelled hormone plus excess unlabelled hormone were incubated with increasing amounts of membrane, it appeared that the membranes did bind glucagon specifically (the binding was displaceable by excess unlabelled hormone) and that binding increased proportionally with the amount of membrane present. For all further experiments $200 \mu \mathrm{g}$ of membrane-protein were added per incubation; this was sufficient to bind $10-14 \%$ of the labelled hormone. Nonspecific binding (radioactivity in precipitates, which was not displaced by excess unlabelled hormone) constituted an average of $8 \%$ of total binding and never exceeded 10\%. A study of the time course of binding (Fig. 1) suggested that equilibrium was reached within $30 \mathrm{~min}$ at room temperature. As dissociation of glucagon (not shown) is very slow under

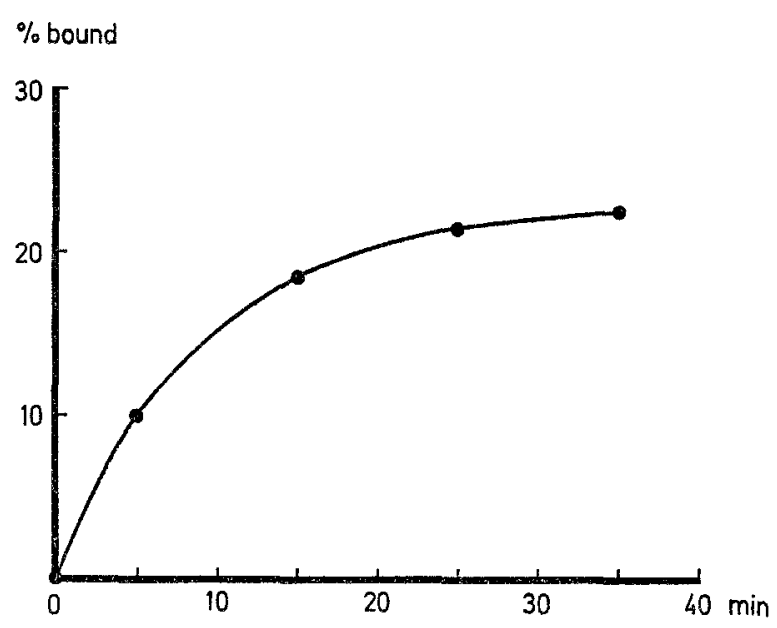

Fig. 1. Time course of binding of 125I-labelled glucagon to pig liver plasma membranes. $200 \mu \mathrm{g}$ membrane protein and $40 \mathrm{pg}$ labelled glucagon in a volume of $2 \mathrm{ml}$ buffer (see text) were incubated at $22^{\circ} \mathrm{C}$. Separation was performed after increasing incubation periods as indicated on the abscissa. Ordinate: per cent of labelled hormone specifically bound to membranes

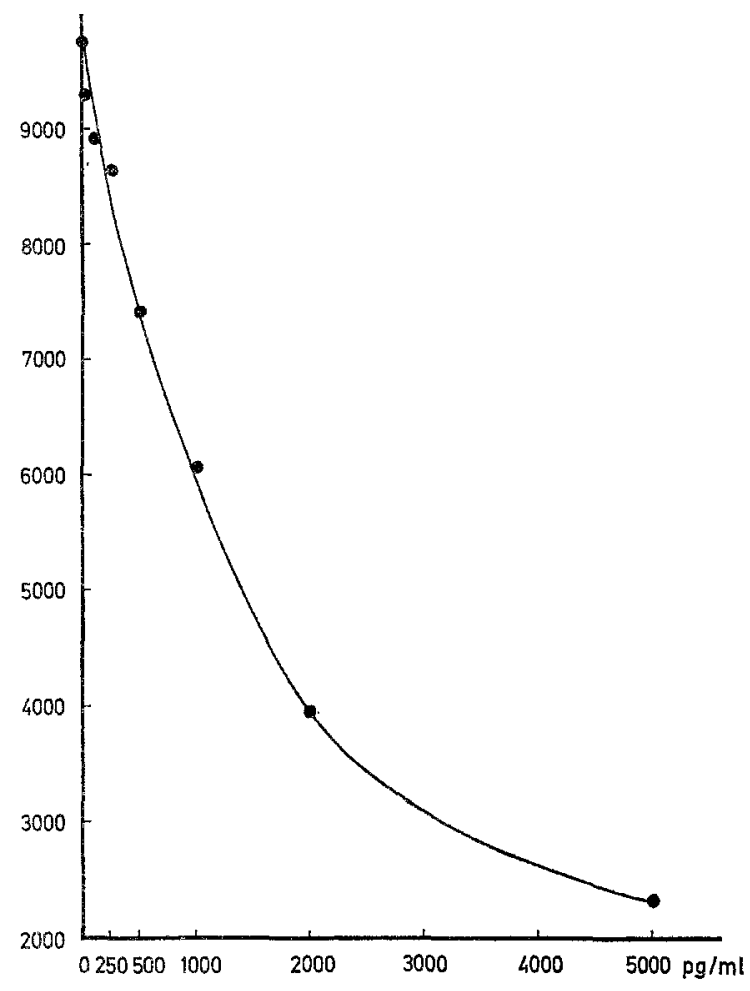

Fig. 2. Standard curve obtained with porcine liver cell membranes, isolated according to Lesko [12]. Incubation conditions as described in the methods section

these conditions [3], standards or samples and receptor were incubated for $30 \mathrm{~min}$ before the addition of a relatively large amount of labelled hormone (100 pg) for a relatively short period $(15 \mathrm{~min})$ before separation. The resulting standard curve is shown in 
Fig. 2. The detection limit of the receptor-assay (the smallest amount that can be discriminated significantly from zero) was $40 \mathrm{pg} / \mathrm{ml}$. Sixfold assays of samples in the low and high range yielded coefficients of variation of $0.06-0.07$.

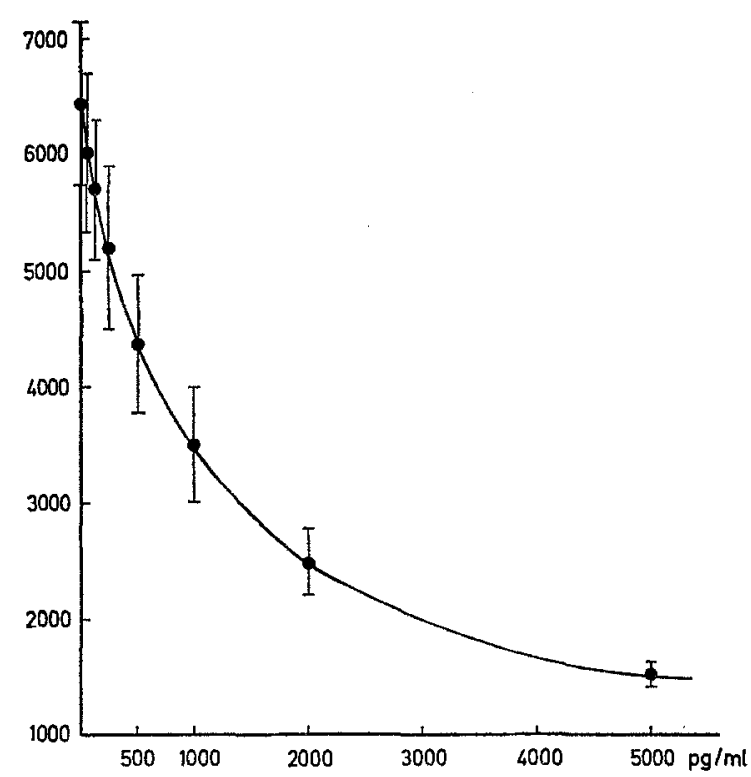

Fig. 3. Reproducibility of standard curves. Means ( \pm SEM) of the values from six consecutive standard curves. Incubation conditions as described in the methods sections. Ordinate: counts in precipitate. Abscissa: concentration of glucagon

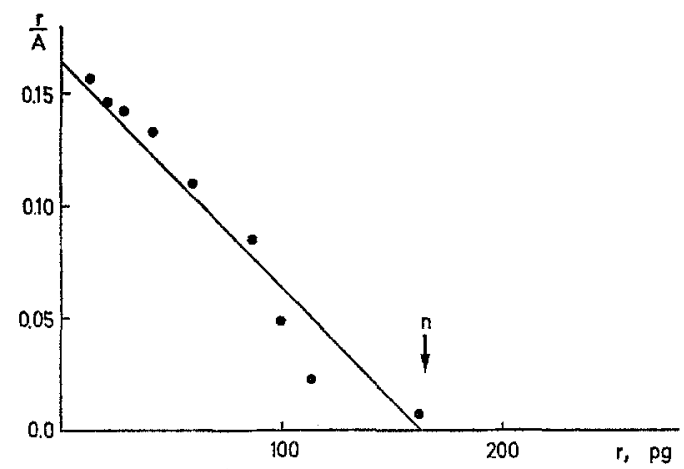

Fig. 4. Scatchard plot [24] of the data from Fig. 2, transformed to fit the equation $r / A=K(n-r)$, where $A$ is the concentration of unbound hormone, $r$ the amount of receptor-bound hormone, $\mathrm{n}$ the maximum binding capacity, and $\mathrm{K}$ the equilibrium constant

The means ( \pm SEM) of the values from 6 consecutive standard curves are shown in Fig. 3. The variation is largely due to variations in the quality of the labelled hormone, the binding activity of which decreased upon storage, which was also demonstrated in the radioimmunoassay.
The binding capacity of the membranes and the equilibrium constant, $\mathbf{K}$, for the hormone-receptor reaction were calculated by Scatchard analysis [24] of the data of Fig. 2. A straight line was the best fit to the results (Fig. 4). Hence the binding capacity was

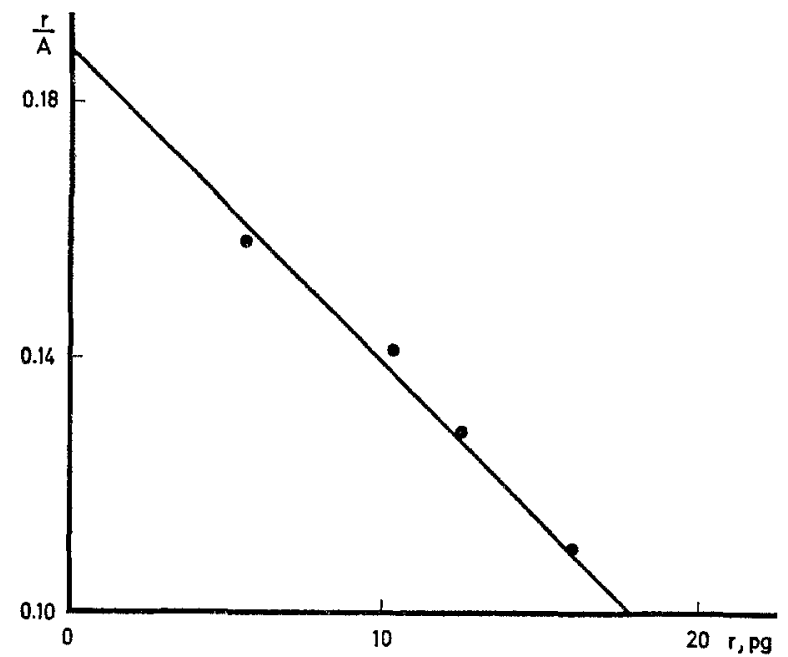

Fig. 5. Binding of ${ }^{125}$ I-labelled glucagon to liver cell plasma membranes. Increasing amounts of labelled glucagon were incubated with membranes for 45 min (specific activity 200 $\mu \mathrm{Ci} / \mu \mathrm{g})$. The binding data were transformed to fit the equation $\mathbf{r} / \mathbf{A}=\mathbf{K}(\mathrm{n}-\mathbf{r})$, where $A$ is the concentration of unbound hormone, $r$ the amount of receptor-bound hormone, $n$ the maximum binding capacity, and $\mathrm{K}$ the equilibrium constant; a plot was constructed of $r$ /a versus $r$ according to Scatchard [24]

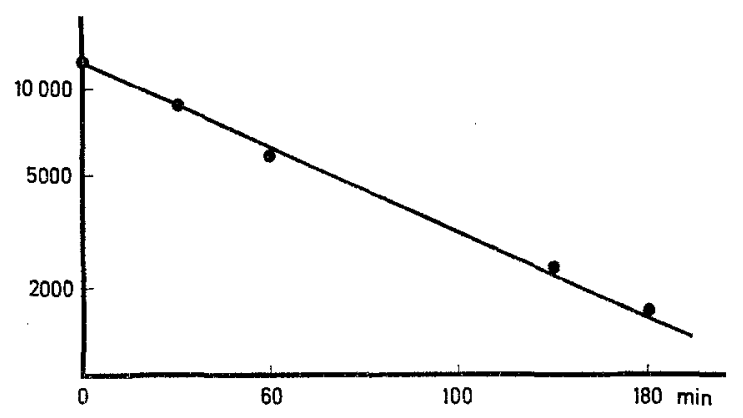

Fig. 6. Degradation of membranes at room temperature. Membranes were suspended in incubation buffer, and labelled hormone was added for 15 minutes at the times indicated on the abscissa. Separation was performed by centrifugation as described in the methods section. The bound radioactivity is plotted against preincubation time. Ordinate: counts in precipitate (note logarithmic scale)

$163 \mathrm{pg} / 200 \mu \mathrm{g}$ membranes or $0.5 \mathrm{pmol} / \mathrm{mg}$ membrane protein, and $\mathrm{K}=7.0 \times 10^{9} \mathrm{l} / \mathrm{mol}$. The equilibrium constant for the binding of labelled glucagon to liver cell membranes was determined from Scatchard analysis [24] of data from an experiment in which increasing amounts of labelled hormone were incubated 
with membranes for 45 minutes, i.e. the total incubation time of the assay (Fig. 5). K was now $7.0 \times 10^{10}$ $1 / \mathrm{mol}$.

The membranes were found to retain binding activity for more than 6 months when stored at $-60^{\circ} \mathrm{C}$,

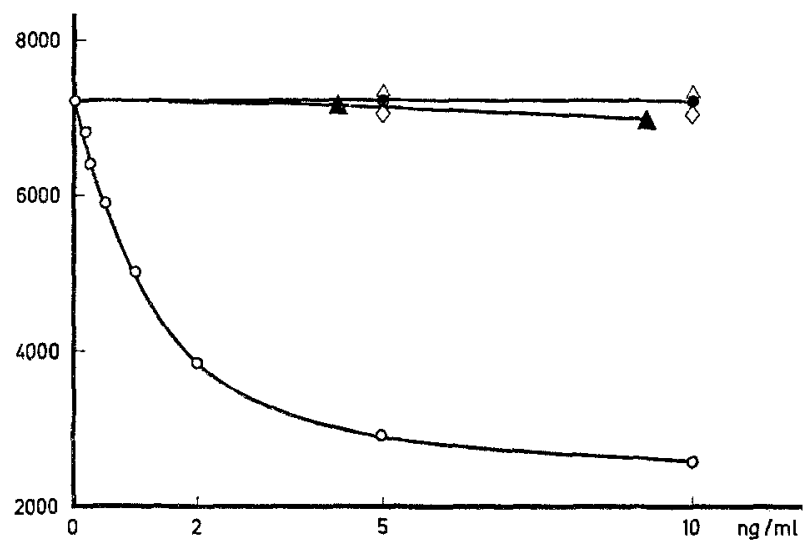

Fig. 7. Specificity of the receptor assay. Membranes were incubated with various concentrations of glucagon $(0)$, insulin (A), gastrin $(\Delta)$, secretin $(\diamond)$ or Vasoactive Intestinal Polypeptide $(\bullet)$. Incubation conditions as described in the methods section. Ordinate: ${ }^{125}$ I-labelled glucagon bound to membranes (counts in precipitate). Abscissa: concentration of peptides

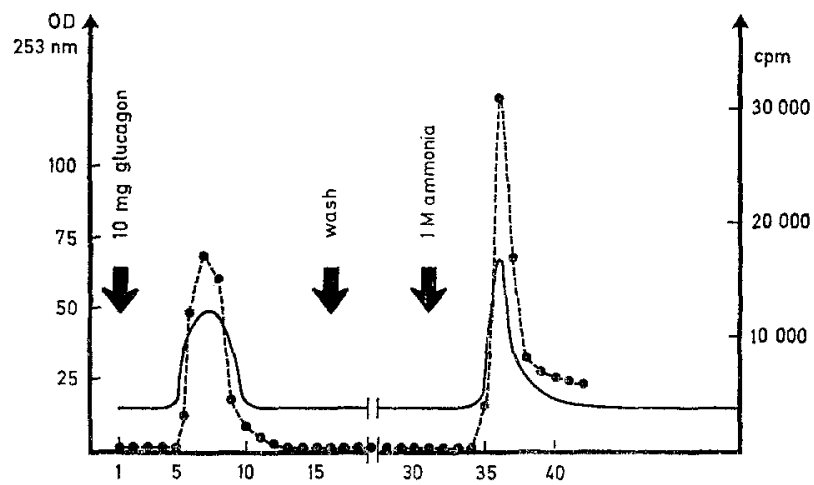

Fig. 8. Capacity of anti-glucagon immunosorbent column. $10 \mathrm{mg}$ glucagon (NOVO) in $10 \mathrm{ml} 0.4 \mathrm{M}$ sodium phosphate buffer, $\mathrm{pH} 7.5$, containing in addition a trace amount of ${ }^{125} \mathrm{I}$ labelled glucagon, was applied on an anti-glucagon column (see text), which was equilibrated with $0.05 \mathrm{M}$ sodium phosphate buffer, $\mathrm{pH} 7.5$, containing in addition $0.15 \mathrm{M} \mathrm{NaCl}$. Flow was not interrupted. After the breakthrough (fractions $5-12)$ the column was washed extensively with equilibration buffer. The bound glucagon was subsequently eluted with $1 \mathrm{M}$ ammonia. Left column: readings (-) in arbitrary units from Uvicord (LKB), right column: radioactivity $(\cdots \cdots)$ in collected fractions $(3 \mathrm{ml})$ of the column effluent (abscissa)

and for more than 5 months when freeze-dried and stored at $-20^{\circ} \mathrm{C}$. With membranes in suspension at $0^{\circ} \mathrm{C}$ binding capacity was halved in $7 \mathrm{hrs}$ and reduced to $10 \%$ after $20 \mathrm{hrs}$. Refreezing also destroyed binding activity.
The rather rapid loss of binding capacity at $0^{\circ} \mathrm{C}$ prompted an investigation of the degradation of membranes in suspension in assay buffer at room temperature (Fig. 6). A monoexponential loss of capacity with

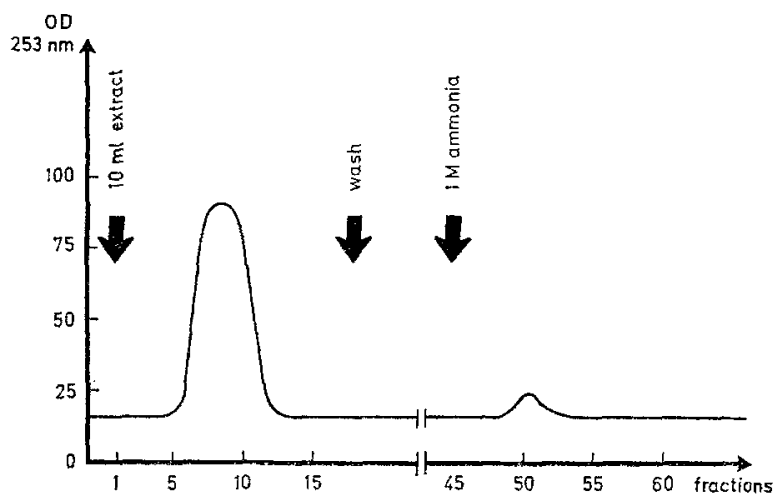

Fig. 9. Affinity chromatography of porcine intestinal mucosa extracted according to Kenny [16]. Freeze-dried extract of $100 \mathrm{~g}$ mucosa dissolved in $10 \mathrm{ml} 0.4 \mathrm{M}$ sodium phosphate, pH 7.5, was applied to an antiglucagon column, which was equilibrated with $0.05 \mathrm{M}$ sodium phosphate buffer, $\mathrm{pH} 7.5$, containing in addition $0.15 \mathrm{M} \mathrm{NaCl}$. After the breakthrough (fractions $5-12$ ) the column was washed extensively with $0.125 \mathrm{M}$ ammonium-bicarbonate, and bound material was subsequently eluted with $1 \mathrm{M}$ ammonia. Abscissa: collected fractions $(3 \mathrm{ml})$ of column effluent. Column at left: readings in arbitrary units from a Uvicord (LKB)

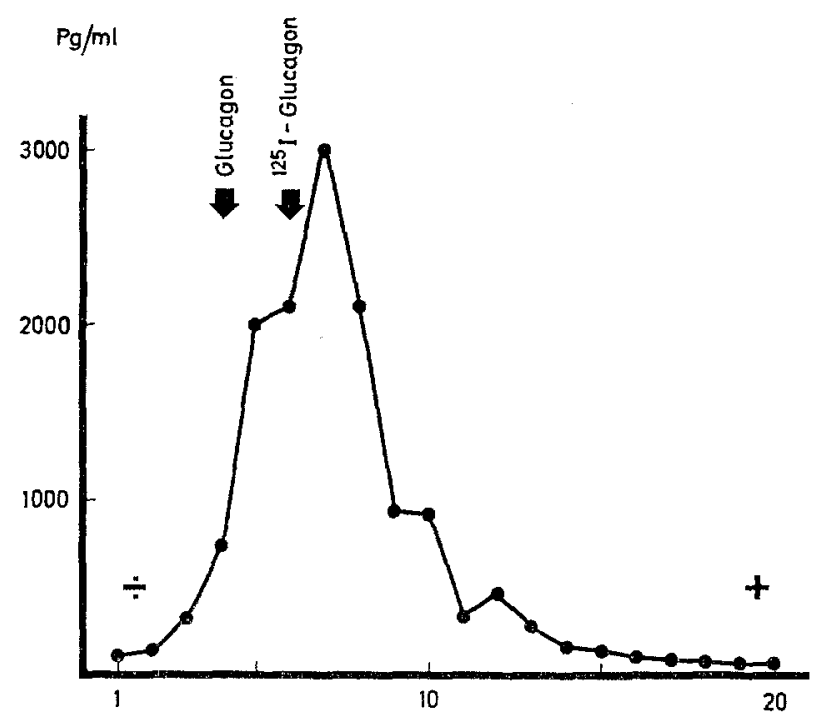

Fig. 10. Polyacrylamide gel-electrophoresis of purified enteroglucagon. Concentration of enteroglucagon in $2 \mathrm{~mm}$ sections of gel eluted with $2 \mathrm{ml}$ buffer for radioimmunoassay. Abscissa: number of section. Ordinate: concentration of enteroglucagon

a half life of $60 \mathrm{~min}$ was found. Because of the instability of the membranes only small series of incubations were performed at a time, and all manipulations were performed simultaneously or as fast as possible. 
The results of the specificity-analysis are shown in Fig. 7. None of the peptides tested were able to inhibit binding of labelled glucagon. When cholecystokinin was assayed in a calculated concentration of $100 \mathrm{ng}$ of cholecystokinin/ml, a crossreaction of $0.8 \%$ was noted. This preparation contained $2 \mathrm{ng} / \mathrm{ml}$ of glucagon-like immunoreactivity, as determined by radioimmunoassay.

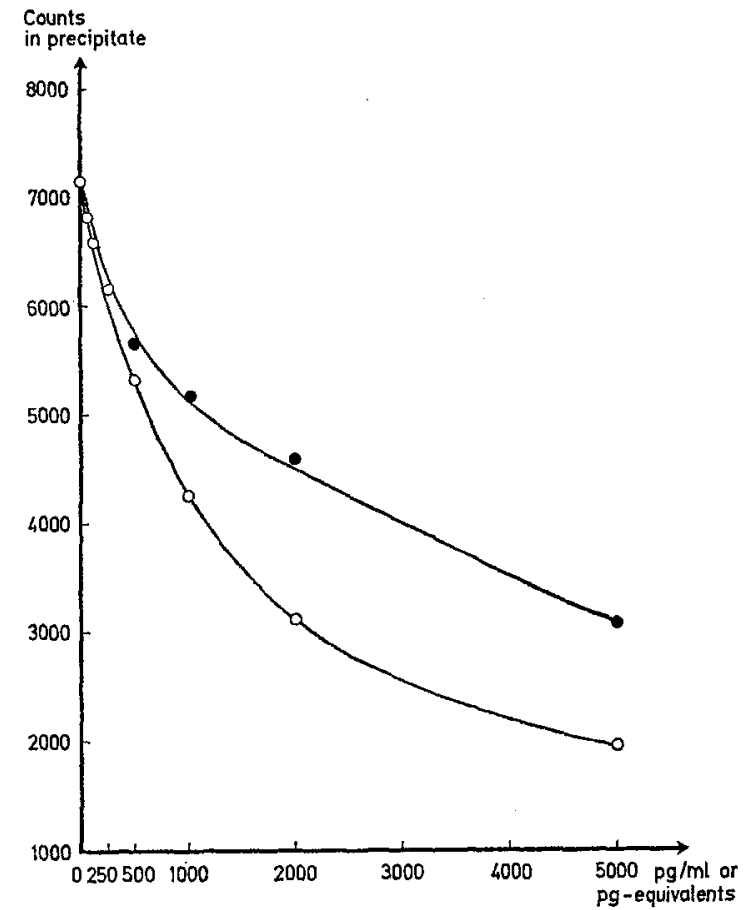

Fig. 11. Binding of enteroglucagon (MUC 101) to pig liver plasma membranes. Dilutions of pancreatic glucagon and enteroglucagon are compared. Incubation conditions as described in the methods section. Ordinate: counts in precipitate. Abscissa: concentrations of glucagon (open circles) and concentrations of enteroglucagon (closed circles) as measured by radioimmunoassay [18] against standards of glucagon

\section{Enteroglucagon}

MUC 101 was found to contain $600 \mathrm{ng}$ equivalents gut glucagon $/ \mathrm{mg}$. This value was found also with a different antiserum [21].

The results of the affinity chromatography can be seen in Figs. 8 and 9. The capacity of the column was $5 \mathrm{ing}$ of pancreatic glucagon. Recovery of radioactivity was $96 \%$. As expected a large amount of UVabsorbing material, which did not contain glucagon immunoreactivity, passed the column unretarded when Kenny extract was applied (Fig. 9). Enteroglucagon was eluted subsequently in sufficient amounts to be detected by the Uvicord. The collected fractions (47-66) were freeze-dried; a total of $1 \mathrm{mg}$ of protein was eluted. In contrast with the data obtained with MUC 101, neither Kenny extracts nor the purified material yielded dilution-curves superimposable on dilutions of pancreatic glucagon when subjected to radioimmunoassay. It is therefore not possible to calculate the enteroglucagon content of these preparations. Estimates from dilutions within the

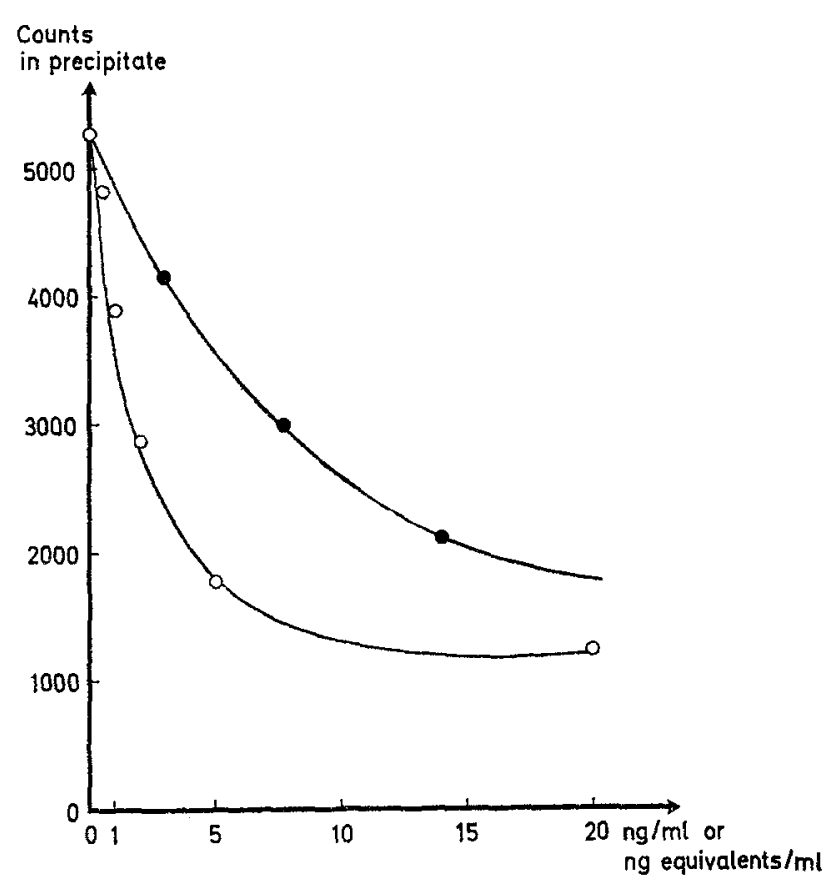

Fig. 12. Binding of enteroglucagon purified by affinity chromatography to pig liver plasma membranes. Dilutions of pancreatic glucagon (open circles) and enteroglucagon (closed circles) are compared. Incubation conditions as described in methods section. Ordinate: counts in precipitate. Abscissa: concentrations of glucagon and apparent concentrations of enteroglucagon as measured by radioimmunoassay [18] against standards of glucagon

working range of the assay, however, suggest a purity of $10 \mu \mathrm{g}$ weight equivalents of pancreatic glucagon/ $\mathrm{mg}$ protein, which means a purification of 100 times by affinity chromatography.

When subjected to polyacrylamide gel-electrophoresis, the bulk of the purified enteroglucagon eluted as a single peak close to the position of labelled glucagon; both labelled and unlabelled glucagon were located in sharp bands $(1 \mathrm{~mm})$, contrasting with the width of the enteroglucagon peak (Fig. 10).

No bands were seen upon staining with amido black.

When enteroglucagon, regardless of preparation, was incubated with membranes, it prevented the 
binding of labelled glucagon to the receptor in a concentration-dependent manner. The inhibition curves were never parallel to the standard curves. Dilution curves of MUC 101 and purified enteroglucagon are shown in Figs. 11 and 12; the concentrations of immunoreactive material are shown on the abscissa.

The apparent affinity of enteroglucagon to the receptors is lower than that of glucagon; 2.4 (Fig. 11) and 4.6 (Fig. 12) times higher concentrations of enteroglucagon are needed to decrease the binding of labelled glucagon by $50 \%$. These dilution curves resemble those obtained with usual antisera against glucagon [21]. Concentrations of enteroglucagon lower than $500 \mathrm{pg}$ equivalents $/ \mathrm{ml}$ significantly interfere with binding of the labelled glucagon (Fig. 11).

\section{Discussion}

In the search for a suitable receptor-preparation for the development of a glucagon-radioreceptorassay, liver cell plasma membranes were chosen, because the liver appears to be the most important target organ for the physiological action of glucagon [25], and because glucagon binding sites of high affinity were described for rat liver plasma membranes [1]. Secondly, pig livers were chosen, because it was intended to investigate the behaviour of porcine enteroglucagon in the receptor-assay. Thirdly, the method of Brunette and Till [11], as described by Lesko [12], was chosen for the isolation of plasma membranes because of its simplicity and the reported high yield and purity of the product. Isolation of plasma membranes from pig liver has been described by Lutz and Frimmer [26]; their method of isolation, however, is quite complicated and takes more than $24 \mathrm{hrs}$, which is less desirable when recovery of biological activity is intended. The few modifications of the homogenization procedure described made possible the purification of pig liver plasma membranes in high yield $(1 \mathrm{mg}$ membrane protein per $g$ liver, wet weight) and within $7 \mathrm{hrs}$. It is assumed that the purity of the membranes prepared in this way is similar to that described by Lesko [12]; the conventional enzyme markers have not been checked nor have the membranes been submitted to electron microscopy, as the only requirement the preparation should meet was specific binding of glucagon.

Sufficient sensitivity of the receptor-assay was obtained by 1) the use of large standard- or samplevolumes, which increased the absolute amount of hormone available for binding, and 2) preincubation of membranes with standards or samples before addition of labelled hormone; because of the almost irreversible binding of the hormone in buffer milieu, this system resembles back-titration techniques [27] more than competitive protein-binding.

The percentage bound in the system is low, only a few per cent. Repeated washes of the membranes (a minimum of three times is required), however, ensure adequate precision of the assay. Furthermore, a high percentage bound can be obtained, as binding is a simple function of the amount of membranes present; $70 \%$ binding of the label was found in an experiment with large amounts of membrane. As these experiments were rather prodigal of material, no attempts were made to increase this value further. With excess antiserum $95 \%$ of the label was bound. The detection limit of the system $(40 \mathrm{pg} / \mathrm{ml})$ is below the concentrations of circulating glucagon usually reported [28].

The equilibrium constant $\left(7 \times 10^{9} \mathrm{l} / \mathrm{mol}\right)$ and the binding capacity $(0.5 \mathrm{pmol} / \mathrm{mg}$ membrane protein) determined from the present experiments differ from the corresponding values obtained with rat liver membranes [29]. The values, however, clearly depend on incubation conditions (and degradation of membranes), and the system hardly reaches true equilibrium. Surprisingly, the equilibrium constant for binding of labelled glucagon alone was larger than that obtained with unlabelled glucagon. The two experiments are not quite comparable, but the results are consistent with the finding of Bromer et al. [30] that iodoglucagon has increased biological activity compared with unsubstituted glucagon.

\section{Binding of Enteroglucagon}

The glucagon-like activity of extracts of gastrointestinal mucosa, first described by Sutherland and DeDuve [31], later believed to possess glucagon-like immunoreactivity as well [32], has been named gut glucagon [33], gut Glucagon-Like-Immunoreactivity [34] or enteroglucagon [35]. Neither the chemical nature, nor the metabolic role of enteroglucagon is understood at present. A number of components of different molecular weight and charge, and several biological activities have been proposed $[4,5,36]$.

Identity between the glycogenolytic factor of Sutheriand [37] and one of the fractions of the immunoreactive substances has been suggested [5], but this has been difficult to prove $[6,8,37]$. Furthermore, the discovery of VIP (Vasoactive Intestinal Polypeptide) [38], which has about 50\% of the glycogenolytic potency of glucagon and is present in large amounts in extracts of intestinal mucosa $[9,39]$, renders this suggestion even more hypothetical. Recently the presence of a glucagon-like substance indistinguishable from pancreatic glucagon by immunochemical and physico-chemical methods, in the fundic mucosa of the canine ventricle has been reported by 
Unger [40]. This substance may be the original glycogenolytic factor which was also extracted from canine ventricle. There have been no reports, however, on the presence of an analogous substance in the porcine or human gastrointestinal tract. The enteroglucagon preparations employed in the present investigation contained less than $3 \%$ of pancreatic glucagon-like immunoreactivity, compared to the total immunoreactivity, when measured with an antiserum relatively specific for pancreatic glucagon (4317) [18].

Bataille et al. [7,9] have shown that crude extracts interfere with binding of labelled glucagon to rat liver membranes; this was not noted by Pohl [8] or Murphy et al. [6], the latter employing a purified preparation. In the present study, three different preparations of enteroglucagon were analysed; all were porcine and analysed with porcine hepatic plasma-membranes. While MUC 101 yielded linear dilutions and superimposability to standards in the radioimmunoassay (thereby permitting quantification), the Kennyextracts, and hence the purified product thereof, did not. There are two possible explanations of this, both of which may be contributory: 1) enteroglucagon is rapidly degraded to fragments of less immunoreactivity at room temperature [21], and 2) the precipitation techniques employed in the preparation of MUC101 may irreversibly destroy immunoreactivity of fragments, or components, that do not give linear dilutions in the radioimmunoassay. The pattern of immunoreactivity obtained with the purified enteroglucagon after polyacrylamide gel-electrophoresis suggests some heterogeneity of the preparation consistent with the results of Murphy et al. [6].

However, the aim was to investigate the effect of total enteroglucagon, that is the total immunoreactivity of the porcine intestinal mucosa, and constantly a concentration-dependent inhibition of the binding of ${ }^{125}$ I-labelled glucagon was observed. That this is the case with the purified enteroglucagon also indicates that the inhibition is not merely non-specific interference, nor an effect of other hormones present in the crude extracts. Furthermore, when tested for crossreaction with other available peptides, the receptors appeared highly specific. The crossreaction noted with $10 \%$ pure cholecystokinin is fully explained by the enteroglucagon-content of this preparation. In accordance with the results of Bataille et al. [7, 9], enteroglucagon was found to bind to the membranes with lower affinity than glucagon; depending on the preparation, 2-4 times more enteroglucagon was needed to reduce binding of labelled glucagon by $50 \%$. This is consistent with the data of Bataille et al. [7] for the fraction " $B$ ". In spite of the lower affinity, physiological concentrations of enteroglucagon are readily detected in the receptor-assay; concentrations higher than $500 \mathrm{pg}$ equivalents/ml (Fig. 11) are seen after fat-meals [11],during oral glucose tolerance tests [21] and under various pathological conditions [42, 43].

The results indicate that enterglucagon may bind to the hepatic receptors in vivo also; but this does not necessarily mean that the enteroglucagon will stimulate adenyl-cyclase or promote glycogenolysis. Firstly, not all receptors seem to be connected with adenyl-cyclase activity [44]; this, however, may be an artefact of preparation [45]. Secondly, glucagon fragments, shown to interfere with binding, may not stimulate adenyl-cyclase [46, 47]. The activation described by Bataille et al. [7, 9] may result from the action of coextracted VIP or of other not yet characterized hormones. It has been proposed that increased release of enteroglucagon during reactive hypoglycemia might competitively inhibit glucagon-stimulated glycogenolysis [4, 43]; this hypothesis gains some support from the present results.

Acknowledgements. This study was supported by grants from "Statens Lxgevidenskabelige Forskningråd", nos. $512-2540,512-2661$, and 512-3717. The expert technical assistance of Rikke Grønholdt is gratefully acknowledged.

\section{References}

1. Rodbell, M.: Regulation of glucagon action at its receptors. In: Lefèbvre, P. J., Unger, R. H.: Glucagon, pp. 61-75. Oxford: Pergamon Press 1972

2. Birnbaumer, L.: Hormone-sensitive adenylyl-cyclases. Useful models for studying hormone receptor functions in cell-free systems. Biochim. biophys. Acta (Amst.) 300, 129-158 (1973)

3. Rodbell, M.: The problem of identifying the glucagon receptor. Fed. Proc. 32, 1854-1858 (1973)

4. Moody, A. J.: Gastrointestinal glucagon-like immunoreactivity. In: Lefèbvre, P. J., Unger, R. H.: Glucagon, pp. 319-341. Oxford: Pergamon Press 1972

5. Valverde, I., Rigopoulou, D., Marco, J., Faloona, G. R., Unger, R. H.: Characterization of glucagon-like immunoreactivity (GLI). Diabetes $19,614-623(1970)$

6. Murphy, R. F., Buchanan, K. D., Elmore, D. T.: Isolation of glucagon-like immunoreactivity of gut by affinity chromatography on antiglucagon antibodies coupled to Sepharose 4B. Biochim. biophys. Acta (Amst.) 293, 118-127 (1973)

7. Bataille, D. P., Freychet, P., Kitabgi, P. E., Rosselin, G. E.: Gut glucagon: A common receptor site with pancreatic glucagon in liver cell plasma membranes. FEBS letters 30, 215-218 (1973)

8. Pohl, S. L., Chase, L. R.: A radioreceptor assay for glucagon using purified plasma membranes from rat liver. Excerpta Medica, International Congress Series 256, 201 (1972)

9. Bataille, D., Freychet, P., Rosselin, G.: Interactions of glucagon, gut glucagon, vasoactive intestinal polypeptide and secretin with liver and fat cell plasma membranes: binding to specific sites and stimulation of adenylate cyclase. Endocrinology 95, 713-721 (1974) 
10. Lefkowitz, R. J., Roth, J., Pastan, I.: Radioreceptor assay of adrenocorticotropic hormone: New approach to assay of polypeptide hormones in plasma. Science 170, 633$635(1970)$

11. Brunette, D. M., Till, J. E.: A rapid method for the isolation of L-cell surface membranes using an aqueous two-phase polymer system. J. Membrane Biol. 5, 215224 (1971)

12. Lesko, L., Donlon, M., Marinetti, G. V., Hare, J. D.: A rapid method for the isolation of rat liver plasma membranes using an aqueous two-phase polymer system. Biochim. biophys. Acta (Amst.) 311, 173-179 (1973)

13. Ray, T. R.: A modified method for the isolation of the plasma membrane from rat liver. Biochim. biophys. Acta (Amst.) 196, 1-9 (1970)

14. Jørgensen, K. H., Larsen, U. D.: Purification of ${ }^{125} \mathrm{I}$-glucagon by anion exchange chromatography. Horm. Metab. Res. 4, 223-224 (1972)

15. Moody, A. J., Markussen, J., Schaich Fries, A., Steenstrup, G., Sundby, F., Malaisse, W., Malaisse-Lagae, F.: The insulin releasing activities of extracts of porcine intestine. Diabetologia 6, 135-140 (1970)

16. Kenny, A. J., Say, R. R.: Glucagon-like activity extractable from the gastro-intestinal tract of man and other animals. J. Endocr. 25, 1-7 (1962)

17. Cuatrecasas, P.: Affinity chromatography of macromolecules. In: Meister, A.: Advances in Enzymology 36, pp. 29-89. New York: Academic Press 1972

18. Holst, J. J., Aasted, B.: Production and evaluation of glucagon antibodies for radioimmunoassay. Acta Endocr. (Kbh.) 77, 715-726 (1974)

19. Wide, L.: Radioimmunoassays employing immunosorbents. Acta Endocr. (Kbh.) 142, 207-221 (1969)

20. Holst, J. J.: Release of gut-GLI from human intestine in vitro. Acta Endocr. (Kbh.) Suppl. 177, 331 (1973)

21. Heding, L. G.: Radioimmunological determination of pancreatic and gut glucagon in plasma. Diabetologia 7, 1019 (1971)

22. Lowry, O. H., Rosenbrough, N. J., Farr, A. L., Randall, R. J.: Protein measurement with the Folin phenol reagent. J. biol. Chem. 193, 265-275 (1951)

23. Maurer, H. R.: Dise electrophoresis. p. 44. Berlin: De Gruyter 1971

24. Scatchard, G.: The attractions of proteins for small molecules and ions. N.Y. Acad. Sci. 51, 660-672 (1949)

25. Lefèbvre, P. J., Unger, R. H.: Glucagon. Oxford: Pergamon Press 1972

26. Lutz, F., Frimmer, M.: A new method for the isolation of plasma membranes from pig liver. Hoppe-Seylers $Z$. physiol. Chem. 351, 1429-1434 (1970)

27. Wright, P. H., Makulu, D. R., Vichik, D., Sussman, K. E.: Insulin immunoassay by back-titration: Some characteristics of the technic and the insulin precipitant action of alcohol. Diabetes 20, 33-45 (1971)

28. Luyckx, A. S.: Immunoassays for glucagon. In: Lefèbvre, P. J., Unger, R. H.: Glucagon, pp. 285-297. Oxford: Pergamon Press 1972

29. Rodbell, M., Krans, H. M. J., Pohl, S. L., Birnbaumer, L.: The glucagon-sensitive adenyl cyclase system in plasma membranes of rat liver. III. Binding of glucagon: Method of assay and specificity. J. biol. Chem. 246, 1861-1871 (1971)

30. Bromer, W. W., Boucher, M. E., Patterson, J. M.: Glucagon structure and function. II. Increased activity of iodoglucagon. Biochem. biophys. Res. Commun. 53, 134139 (1973)
31. Sutherland, E. W., DeDuve, C.: Origin and distribution of the hyperglycemic-glycogenolytic factor of the pancreas. J. biol. Chem. 175, 663-674 (1948)

32. Unger, R. H., Eisentraut, A. M., Sims, K., McCall, M. S., Madison, L. L.: Sites of origin of glucagon in dogs and humans. Clin. Res. 9, 53 (1961)

33. Samols, E., Marks, V.: In: Journées annuelles de diabétologie de 1: Hotel-Dieu, pp. 43-66. Paris: Editions Médicales Flammarion 1967

34. Unger, R. H., Ohneda, A., Valverde, I., Eisentraut, A. M., Exton, J.: Characterization of the responses of circulating glucagon-like immunoreactivity to intraduodenal and intravenous administration of glucose. J. clin. Invest. 47, $48-65$ (1968)

35. Unger, R. H., Eisentraut, A. M.: Glucagon. In: Gray, C. H., Bacharach, A. L.: Hormones in Blood, 1, 83, New York 1967

36. Gutman, R. A., Fink, G., Voyles, N., Selawry, H., Penhos, J. C., Lepp, A., Recant, L.: Specific biological effects of intestinal glucagon-like materials. J. clin. Invest. 52, 1165-1175 (1973)

37. Marco, J., Faloona, G. R., Unger, R. H.: Effect of endogenous intestinal glucagon-like immunoreactivity (GLI) on insulin secretion and glucose concentration in dogs. $J$. clin. Endocr. 33, 318-325 (1971)

38. Said, S. I., Mutt, V.: Polypeptide with broad biological activity: isolation from small intestine. Science 169, $1217-1218$ (1970)

39. Kerins, C., Said, S. I.: Hyperglycemic and glycogenolytic effects of Vasoactive Intestinal Polypeptide. Proc. Soc. exp. Biol. (N.Y.) 142, 1014-1017 (1973)

40. Unger, R. H., Orci, L.: The essential role of glucagon in the pathogenesis of diabetes mellitus. Lancet 1975 I, 1416

41. Böttger, I., Dobbs, R., Faloona, G. R., Unger, R. H.: The effects of triglyceride absorption upon glucagon, insulin, and gut glucagon-like immunoreactivity. J. clin. Invest. 52, 2532-2541 (1973)

42. Bloom, S. R., Royston, C. M. S., Thomson, J. P. S.: Enteroglucagon release in the dumping syndrome. Lancet 1972 II, 789-791

43. Rehfeld, J. F., Heding, L. G., Holst, J. J.: Increased gut glucagon release as a pathogenetic factor in reactive hypoglycemia? Lancet 1973 I, 116-118

44. Birnbaumer, L., Pohl, S. L.: Relation of glucagon-specific binding sites to glucagon-dependent stimulation of adenylyl cyclase activity in plasma membranes of rat liver. J. biol. Chem. 248, 2056-2061 (1973)

45. Jarret, L., Reuter, M., McKeel, D. W., Smith, R. M.: Loss of adenyl cyclase hormone receptors during purification of fat cell plasma membranes. Endocrinol. 89, 1186-1190 (1971)

46. Rodbell, M., Birnbaumer, L., Pohl, S. L., Sundby, F.: The reaction of glucagon with its receptor: Evidence for discrete regions of activity in the glucagon molecule. Proc. nat. Acad. Sci. (Wash.) 68, 909-913 (1971)

47. Birnbaumer, L., Pohl, S. L., Rodbell, M.: The glucagonsensitive adenylate cyclase system in plasma membranes of rat liver. J. biol. Chem. 247, 2038-2043 (1972)

J. J. Holst, M.D.

Dept. of Gastroenterology A

Undervisningsbygning I

Bispebjerg Hospital

Bispebjerg Bakke 23

DK-2400 København NV

Denmark 